\title{
The Influence of Exchange Rate Changes on Agricultural Prices: The Case of Cocoa and Maize in Ghana (1966-2008)
}

\author{
Adu-Gyamfi Poku* \\ Social and Institutional Change in Agricultural Development, Hans-Ruthenberg-Institute, \\ University of Hohenheim, Stuttgart, Germany \\ *Corresponding author: adu-gyamfi.poku@uni-hohenheim.de
}

\begin{abstract}
Exchange rates are a key determinant of the domestic prices for agricultural goods and therefore affect the quantity of these goods produced for domestic consumption and export. Accordingly, in competitive domestic markets with complete market integration with foreign markets, exchange rate changes are fully reflected in the domestic currency prices of traded goods. However, agricultural policy instruments such as intervention mechanisms tend to insulate domestic markets and impede exchange rate transmission. The study examines the influence of nominal exchange rate changes in Ghana on the annual domestic producer prices of cocoa, a traditional export crop, and maize, a non-traditional export crop from 1966 to 2008. Nominal exchange rate changes in Ghana were found to reflect the gradual shift from a fixed to a flexible exchange rate regime since independence. Using an Autoregressive Distributed Lag model, it was discovered that exchange rate transmission was extremely low for both crops. Therefore, it did not have a statistically significant effect on domestic producer prices of cocoa and maize in Ghana. Whiles market intervention was found to be the cause of this phenomenon in the case of cocoa, the very nature of maize as a non-traditional export with low export supply accounted for the lack of exchange rate transmission in the maize sub-sector. Consistently, world price transmission to domestic producer prices of both crops was also not statistically significant.
\end{abstract}

Keywords: agricultural prices, exchange rate transmission, price transmission, autoregressive distributed lag, Ghana

Cite This Article: Adu-Gyamfi Poku, “The Influence of Exchange Rate Changes on Agricultural Prices: The Case of Cocoa and Maize in Ghana (1966-2008).” American Journal of Rural Development, vol. 5, no. 3 (2017): 81-89. doi: 10.12691/ajrd-5-3-4.

\section{Introduction}

Since attaining independence in 1957, agriculture has been the mainstay of the Ghanaian economy and continues to be a fundamental instrument in sustainable development. As of 2009, about $80 \%$ of Ghana's total agricultural output is produced on smallholder, family operated farms using rudimentary technology with an estimated 2.74 million households operating farms or rearing livestock. Approximately $50.6 \%$ of the labor force is directly engaged in agriculture. Export earnings from agriculture constitute a major source of foreign exchange, contributing $37 \%$ of Ghana's total foreign exchange earnings in 2009 [23].

Traditional export crops are crops characterized by high value and quality that are primarily grown for export [7]. Cocoa is Ghana's principal traditional export crop and remains the country's single largest export earner [13]. Given the importance of cocoa as a major source of income and foreign exchange, the government has sought to retain a controlling interest in the sub-sector. Therefore since independence, Ghana Cocoa Board (COCOBOD) has been charged with ensuring price stability in the subsector by setting the domestic producer price of cocoa in an annual review of the price at the beginning of each year prior to the actual export of cocoa. COCOBOD also has a monopoly over the external marketing of cocoa [31].

Non-traditional export crops are crops mainly produced for the domestic market and therefore have an intermittent and often low export supply [7]. Maize serves as the most important cereal crop in Ghana and is produced mainly for domestic consumption under a liberalized market system that has effectively operated since 1983 [1]. Government policy for maize has therefore been aimed at increased production for purposes of food security rather than export promotion [22]. However, being a non-traditional export, Ghana also exports maize in years of surplus production.

Both cocoa and maize are predominantly grown rural smallholders. In general, exchange rates are a key determinant of the domestic prices for agricultural goods and therefore affect the quantity of these goods produced for domestic consumption and export [17]. Exchange rate transmission or pass-through therefore refers to the degree to which changes in the exchange rate are reflected in the destination currency prices of traded goods [20]. In competitive domestic markets with complete market 
integration with foreign markets, changes in a country's exchange rate are fully reflected in the domestic currency prices of traded goods. However, agricultural policy instruments and mechanisms such as state trading, import tariffs and export subsidies or taxes tend to insulate domestic markets, thus impeding market integration and full exchange rate and price transmission. Incomplete exchange rate and price transmissions create a price gap or wedge between the domestic prices and world prices of traded commodities such that market incentives to produce and export these goods are distorted [1,12]. Since independence, changes in Ghana's nominal exchange rate against major trading currencies have reflected the gradual shift from a fixed to a flexible exchange rate regime. The degrees to which these changes have been transmitted to the domestic producer prices of cocoa and maize have been greatly affected by the government agricultural policies supporting these crops.

For traded goods, exchange rates facilitate spatial price transmission between markets by linking domestic prices to world prices such that domestic producers can fully benefit from increased international demand as signaled by high world prices which promote production and exports [17]. However, in many developing countries such as Ghana, exchange rate and world price transmissions to the domestic prices of agricultural commodities are usually impeded by trade policies and intervention mechanisms. This creates a price gap between prices in the domestic and world markets, and can thus have adverse effects on the price incentive to produce and export these commodities. This in turn has wider implications for the economic welfare of domestic producers as well as the foreign exchange earnings of the country, especially in the case of an agrarian economy such as Ghana.

The study aims to establish the extent to which changes in Ghana's nominal exchange rate influence the domestic producer prices of cocoa and maize in light of the agricultural policies supporting the production and marketing of these crops. These crops were chosen because of their importance to the Ghanaian economy as well as the fact that they represent the two major types of agricultural exports, that is, traditional and non-traditional exports. Cocoa is Ghana's most important export crop as it is the country's highest export earner. Maize on the other hand is the most consumed crop in Ghana and is central to the country's food security policy. Therefore, by examining the influence of exchange rate changes on cocoa and maize prices, the study seeks to provide insight into how the distinct policies of these major crops affect the degree of exchange rate pass-through in Ghana. An Autoregressive Distributed Lag (ADL) model is employed using annual time series data from the period of 1966 to 2008.

\section{Historical Policy Accounts}

\subsection{Exchange Rate Policy in Ghana}

Since independence in 1957, the Republic of Ghana has adopted several variations of fixed and floating exchange rate regimes. These reforms have been greatly influenced by trade policies and divergent political regimes that have been in power since independence. Between 1957 and 1982, Ghana adopted a fixed exchange rate regime as supported by the Bretton Woods system. During this period, the Ghanaian cedi $(\mathbb{\Psi})$ was pegged initially to the British pound ( $£$ ) and then later to the American dollar (\$) [4]. This regime was characterized by a series of administrative controls such as import licenses to address any possible excess demand for foreign exchange [24]. This passive attitude towards exchange rate management was a major contributing factor to the poor performance of the Ghanaian economy in the late 1970s and early 1980s [14].

Trade surpluses were recorded in most years between 1972 and 1982 as imports were quantitatively controlled through foreign exchange allocation by the central bank, the Bank of Ghana (BoG). These surpluses were however achieved at a very low level of trade. The ratio of exports and imports to GDP fell drastically from a little over $20 \%$ in 1970 to approximately 3\% in 1982. High inflation rates averaging over $60 \%$ were mainly caused by the scarcity of foreign exchange amidst fixed exchange rates [29]. The Ghanaian cedi was thus increasingly overvalued, reaching an extremely high overvaluation rate of about $816 \%$ by 1982 [32]. This caused the collapse of domestic production as well as exports and imports, leading to the weakening of the government's tax revenue base and consequently huge fiscal deficits [27]. Again, with foreign exchange rationed and the amount of imports restricted, an illegal parallel foreign exchange market emerged as a major source of finance as smuggling activities thrived. This served to further reduce government revenue [19].

The donor supported Economic Recovery Programme (ERP) of 1983 led to massive reforms in exchange rate policy aimed at realigning the overvalued exchange rate and eliminating the parallel exchange rate market. With the support of the IMF and the World Bank, Ghana effectively moved from a fixed exchange rate regime to a system of multiple exchange rates based on a scheme of bonuses on exchange receipts from exports, and surcharges on exchange payments from imports. Two official rates of $\$ 23.38$ : US $\$ 1.00$ and $\$ 30.00$ : US $\$ 1.00$ were applied to specific payments and receipts [4]. Traditional exports, imports of crude oil, basic foodstuffs, essential raw materials and capital goods were subjected to the first tier rate while non-traditional exports and all other types of imports were subjected to the higher second tier rate. The aim of this strategy was to encourage nontraditional exports by improving the chronically low supply of foreign exchange. Due to the fact that the surcharges on imports were used to finance export bonuses, the strategy avoided any significant budgetary drain on the government [27].

However in October 1983, this system was abandoned and the two rates were merged at $\$ 30.00$ : US\$1.00. Within the PPP framework, a real exchange rate policy rule was introduced requiring periodic adjustments of the exchange rate in accordance with the relative inflation rates of Ghana's major trading partners [9]. Under this crawling peg regime, the exchange rate depreciated from $\$ 30.00$ : US $\$ 1.00$ to $\$ 90.00$ : US\$1.00 by January 1986 . Again, the parallel market premium also declined significantly in this period. With inflation declining and substantially lower 
than these changes in the exchange rate, the desired real devaluation was achieved. The volume of trade, and consequently the base of trade taxes increased substantially as the exchange rate was adjusted to $\$ 90.00$ : US\$1.00. The institution of tax reforms that reduced and simplified custom tariffs to increase efficiency of collection also resulted in import duty collection as a percentage of GDP approximately tripling [16]. A fiscal surplus of $0.06 \%$ of GDP, and a fall in inflation from over $140 \%$ in 1983 to about $30 \%$ was consequently achieved by the end of 1986 [9]. Therefore, the combined effect of the exchange rate and tax reforms resulted in increased revenue and enabled the Ghanaian government to balance its budget, a key condition associated with IMF and World Bank support [16].

The government implemented an auction market approach for determining exchange rates in September 1986 with the aim of achieving further trade liberalization and depoliticizing the issue of exchange rate adjustment [14]. The new arrangement comprised a dual exchange rate system with two windows. A fixed exchange rate which pegged the cedi-dollar exchange rate at $\$ 90.00$ : US\$ 1.00 was operated in the first window. This window was used for official government transactions mainly in relation to earnings from cocoa exports as well as for importing crude oil, processed petroleum products and essential drugs. The second window catered for all other transactions and operated a market determined exchange rate in a weekly auction conducted by the BoG. Authorized dealer banks served as intermediaries by bidding only on behalf of their clients. The banks therefore collated the bids and auction funds of their clients for the BoG [27].

However, in February 1987 the two systems were merged. A dual-retail auction based on a marginal pricing auction system was introduced. Accordingly, using the market determined exchange rate, successful bidders were required to pay the marginal price for the foreign exchange allocated to them. In the second auction, the Dutch auction system was adopted where successful bidders were required to pay the bid price [4]. Unlike the marginal pricing auction system, the Dutch auction system permitted a multiple currency auction where using international conversion rates, successful bidders for currencies other than US dollars were allocated the dollar equivalent. The main aim of this system was to widen access to the auction, thereby expanding coverage of the floating exchange rate arrangement and reducing importer's reliance on the parallel market [27].

The persistent operation of a parallel foreign exchange market prompted the government to legislate the establishment of a private market-oriented foreign exchange (forex) bureaux system in 1988. This was aimed at absorbing the parallel market into the legal foreign exchange market [9]. As fully licensed entities managed by individuals, groups, banks and institutions, these forex bureaux operated concurrently with the auction. The main sources of foreign exchange supply for the forex bureaux were receipts from unofficial (illegal) exports, nontraditional exports, exporters' retention accounts and private remittances as they were not permitted to bid for foreign exchange in the auction. Their main sources of demand for foreign exchange included all imports, legal and illegal, capital transactions and service payments. Ghana's foreign exchange market was therefore once again characterized by two separately quoted rates [27]. The divergence between the bureaux rate and the parallel market rate was found to be increasingly insignificant as both rates were above that of the auction. This signaled the absorption of the parallel market into the legal foreign exchange market. The establishment of the forex bureau system under the ERP therefore effectively liberalized the foreign exchange market and consequently enhanced Ghana's trade liberalization policies [14].

The weekly retail auction was replaced by the wholesale auction in 1990. This system operated a composite exchange rate system comprising an inter-bank market and a wholesale system. In order to eliminate the spread between bureaux buying and selling rates, authorized dealer banks and eligible forex bureaux were permitted to purchase foreign exchange from the BoG to sell to their customers as well as to meet their own foreign exchange needs under the wholesale system. This also served to reduce the divergence between the bureaux and the auction rates. Hence, foreign exchange obtained could now be sold to end-user customers [9]. The wholesale auction system which ran concurrently with the inter-bank market was however discontinued in April 1992, leaving the present inter-bank market where the BoG buying and selling rates are based on the average daily retail rates of commercial banks [4]. This not only eliminated the BoG's dominance in market-making, but also led to the final convergence of the official and parallel exchange rates as the former depreciated towards the latter. This system therefore allows both forex bureaux and the commercial banks to operate in a competitive market environment. Thus, with a gradual change from a fixed to flexible exchange rate regime, Ghana has effectively operated a managed floating exchange rate system since 1986 where intervention by the BoG has mainly been to curb fluctuations in the foreign exchange market [27].

\subsection{Agricultural Policy in Ghana}

Agriculture is the mainstay of the Ghanaian economy and continues to be a fundamental instrument in sustainable development and poverty reduction in Ghana through the creation of employment, provision of food security, generation of foreign exchange earnings and supply of raw materials for industry. Therefore beyond food production, Ghana's agricultural sector has contributed to economic growth through forward linkage activities such as processing and exportation, and backward linkages in terms of the provision of services to the sector. Thus, further growth has been spurred by the spending of incomes earned from all these productive activities. Given the key role the agricultural sector continues to play in the Ghanaian national economy, agricultural policy has formed an intricate part of the broader national policy, the effective implementation of which has been aimed at sustainable growth in incomes and poverty reduction [22].

\subsubsection{The Cocoa Sub-Sector}

With cocoa being Ghana's largest export earner, government policy for the cocoa sub-sector has formed a 
major component of the country's economic policy. The Cocoa Marketing Board (CMB) established in 1947 was set up to protect farmers from price instability through the Pan-Territorial Fixed Price Policy and was thus granted monopoly power over internal and external marketing of cocoa. This pricing system guaranteed farmers a reliable source of income and ensured that the government secured revenue from cocoa as the price was determined prior to the crop being harvested. The authority of the CMB in the cocoa industry extended to input marketing and extension services in cocoa producing areas [31].

Following a period of political and economic instability which upset cocoa production and marketing, the ERP of 1983 resulted in the introduction of the Cocoa Rehabilitation Project (CRP) and the Agricultural Sector Adjustment Programme (ASAP). These reforms were aimed at reducing the costs of inefficient pricing and marketing systems thereby increasing producer prices as well as improving the efficiency of related cocoa activities [31]. This led to a wide array of changes in the structure and activities of the CMB, now the Ghana Cocoa Board (COCOBOD). Thus, COCOBOD gradually began to reduce input subsidies leading to a significant increase in input prices. As a result of COCOBOD also reducing its share in cocoa revenues from $30 \%$ to $15 \%$ of the free on board (f.o.b.) price, coupled with falling inflation, real producer prices increased substantially by 1988 from the low prices in 1983 [6].

The year 1992 marked the end of input marketing and the liberalization of internal marketing. The objective of the liberalization was to improve the financial and operational performance of Ghana's marketing system, so as to enable higher producer prices and halt Ghana's falling production trend [11]. Private Licensed Buying Companies (LBCs) were established to compete with COCOBOD's Produce Buying Company (PBC). Consequently by 1996, the PBC's share of purchases fell to $80 \%$ and subsequently to $37 \%$ by 2001 . The introduction of competition in internal marketing failed to lead to price differentiation as the monopsonistic price setting by COCOBOD has remained in place. The producer price continues to be adjusted to the real price on the market through an annual review of the price and margins. A bonus is however now paid to farmers for supplying cocoa through the LBCs [31]. This producer bonus is computed using the policy determined percentage of the f.o.b. price, standing at $70 \%$ of the net f.o.b. price as of 2009 [13].

In addition to these marketing reforms, COCOBOD merged the extension component of its services division with that of the Ministry of Food and Agriculture (MOFA), providing unified extension services. Again, liberalization of COCOBOD's export monopoly commenced in 2001 where as per a minimum tonnage requirement, LBCs were permitted to directly export $30 \%$ of their cocoa purchases to external buyers [6]. However, in 2007, this partial liberalization was discontinued. Hence, given the importance of cocoa as a major source of income and foreign exchange, the Ghanaian government has sought to retain a controlling interest in the sub-sector, particularly in cocoa exports [31].

\subsubsection{The Maize Sub-Sector}

As one of the staple food crops grown throughout Ghana, maize is mainly produced for domestic consumption and serves as the most important cereal crop in the country [1]. Much like cocoa, procurement of maize in the 1960s was facilitated by the Agricultural Development Board which was responsible for purchasing maize and rice at fixed prices and storing them in an attempt to stabilize prices. This organization was displaced in 1975 by the Ghana Food Distribution Corporation (GFDC). However, the GFDC on average purchased less than $5 \%$ of the maize and rice produced as its efficacy was constrained by poor infrastructure and the lack of storage facilities, with proposals to increase public food storage capacity yielding little results [25].

The ERP of 1983 commenced the liberalization of maize markets in Ghana and the GFDC was dissolved in 1987. In 1990, the government eliminated the guaranteed minimum price paid to farmers for maize amongst other selected food crops. Subsequently, input subsidies for these crops were abolished in 1992 [6]. This marked the beginning of the current fully liberalized commercial system with maize completely marketed by the private sector. Accordingly, wholesale and retail maize prices have been characterized by seasonal fluctuations [1].

As a crop of mixed trade status, maize has been imported in years when local production has been insufficient to meet domestic demand whiles exported in years of surplus production. As of 2009, maize registered the highest output among cereals produced in Ghana with a total output of 1,620,000 metric tonnes and contributed significantly to Ghana's earnings from non-traditional agricultural exports [13]. However, under MOFA's current sector-wide Food and Agriculture Sector Development Policy (FASDEP) support from the government in the form of improved seed production, credit facilitation, storage facilities and appropriate mechanization has been aimed at increased production for purposes of food security rather than export promotion [21,22].

\section{Methodology}

\subsection{Econometric Model}

This research aimed to investigate how changes in Ghana's exchange rate from the period of 1966 to 2008 impacted on domestic producer prices of cocoa and maize over the period. For this analysis, the ADL model was found to be the most appropriate model. This regression model includes lags of both the dependent and independent variables in explaining variability in the dependent variable. Hence, the ADL model measures the effect that the lag(s) of the dependent variable, the explanatory variables and their lags have on the dependent variable. As shown Appendix 1, the study employed Akaike's information criterion (AIC) in determining the optimal lag length as this criterion was found to be most suitable for lag order selection in time series data involving 60 observations or less [18]. The model also allows for the analysis of a deterministic trend. The ADL model is given as:

$$
\begin{aligned}
\mathrm{Y}_{t}= & \alpha+\delta_{t}+\varphi_{1} \mathrm{Y}_{t-1}+\ldots+\varphi_{p} \mathrm{Y}_{t-p}+\beta_{0} X_{t} \\
& +\beta_{1} X_{t-1}+\ldots+\beta_{q} X_{t-q}+e_{t}
\end{aligned}
$$


Where $Y_{t}$ (the dependent variable) depends on $p$ lags of itself, the present value of $X_{t}$ (the independent variable) as well as $q$ lags of $X_{t}$. However, in the event that the variables are non-stationary, the model is rewritten as:

$$
\begin{aligned}
\Delta \mathrm{Y}_{t}= & \alpha+\delta t+\rho \mathrm{Y}_{t-1}+\gamma_{1} \Delta \mathrm{Y}_{t-1}+\ldots+\gamma_{p-1} \Delta \mathrm{Y}_{t-p+1} \\
& +\theta X_{t}+\omega_{1} \Delta X_{t}+\ldots+\omega_{q} \Delta X_{t-q+1}+e_{t} .
\end{aligned}
$$

This form of the model is estimated to address or solve the problem of spurious regression results. Where $\Delta Y$ $\left(Y_{t}-Y_{t-1}\right)$ and $\Delta \mathrm{X}\left(X_{t}-X_{t-1}\right)$ are stationary having been differenced in the first order. This model will be estimated separately for both crops. The long run multiplier of the ADL model is used to measure the effect of a permanent change in $\mathrm{X}$ on $\mathrm{Y}$ and is given by; $-\frac{\theta}{\rho}$. Where $\theta$ is the coefficient of $X_{t}$ and $\rho$ is the coefficient of $\mathrm{Y}_{t-1}$ [15]. The Durbin-Watson (DW) test for autocorrelation and the Augmented Dickey-Fuller (ADF) test [8] were also carried out to ensure reliability of the results (see Appendix 2 and 3).

\subsection{Variables}

As per the aim of the study, the dependent variables used are the annual domestic producer price of both cocoa and maize. The domestic producer price is measured in the local currency, that is, new Ghana cedis (GH4), per metric ton of production. Annual domestic producer price is used because cocoa is an annual crop harvested only once a year. Therefore, even though maize is a seasonal crop harvested twice a year, the annual average maize producer price is used for the sake of uniformity and consistency in the study. Due to the fact that Ghana redenominated its currency in 2007 by dropping four zeros, all the domestic producer prices before 2007 were converted to the new currency $(\mathrm{GH} \&)$ as the time series data include figures up to 2008.

The main independent variable of the study is Ghana's nominal exchange rate. The exchange rate used is the annual average of the new Ghana cedi (GHष) against the US dollar (\$). The US dollar was chosen because it is the main international trading currency. Again, the annual average was used for uniformity and consistency in the study. The exchange rate was already adjusted from source to reflect Ghana's redenomination exercise in the years preceding 2007. It is expected that there will be a positive relationship between changes in the exchange rate and the price of traded goods. Therefore, in the absence of trade policies and market conditions that impede exchange rate transmission, a rise in a country's exchange rate, that is, depreciation of the local currency, should lead to a rise in the price domestic producers receive for traded goods [17].

The world prices of cocoa and maize are another set of independent variables used in the study to explain the domestic producer price of cocoa and maize, respectively. These foreign prices were obtained in US dollars per metric ton, representing the world market prices of these crops traded in US dollars. Again, the annual average world prices were used. In order to accurately estimate the price transmission between domestic and world prices, the annual world prices of cocoa and maize were converted to Ghana cedis using the obtained annual nominal exchange rate of the Ghana cedi against the US dollar. The redenomination exercise was again accounted for. In competitive foreign and domestic markets with full market integration there is complete spatial transmission such that commodities are sold at equilibrium prices differing only by transfer costs when converted to a common currency $[10,26,30]$. Hence, if the condition of market integration exists, it is expected that there will be a direct relationship between domestic and foreign prices [1].

The final independent variable of the study is Ghana's GDP used as a proxy for purchasing power and demand on the domestic market. GDP is measured in Ghana cedis and is already computed annually. These figures were already adjusted for the redenomination from source. GDP can be used as a proxy measure of purchasing power, thereby gauging the level of demand in a country [5]. Therefore it is expected that GDP will have a positive and significant effect on maize, a non-traditional export, as well as a positive effect to some degree on cocoa even though it is mainly produced for export. The log form of all the variables in the study was taken to make them more linear and to allow for the interpretation of the exchange rate and price transmission elasticities.

The study makes use of different secondary data sources. The domestic producer prices of both cocoa and maize were obtained from FAOSTAT. The world prices of both crops were obtained from the IMF's International Financial Statistics (IFS) database, while both the exchange rate and GDP were obtained from the World Bank database.

\section{Results}

The regression results of the estimated ADL model are presented here for both crops. First, the results for cocoa are presented. Subsequently, the results for maize are presented using the same approach.

\subsection{Cocoa}

The regression output in Table 1 is from the estimation of a stationary ADL model and therefore includes lags of the dependent and independent variables. The results reported an R-squared of 30\% from regressing domestic cocoa price differenced in the first order on the exchange rate, world cocoa price and GDP all differenced in the first order using the ADL model.

It is found that the exchange rate was not statistically significant. The lag of exchange rate (one year) on the other hand had a significant effect on domestic cocoa price. Therefore there is an exchange rate transmission elasticity of $0.36 \%$ such that a $1 \%$ increase in last year's exchange rate, that is, depreciation of the Ghana cedi (GH4) against the US Dollar (\$), stimulates a $0.36 \%$ increase in domestic cocoa price. This holds true given that the Ghanaian cocoa sector is highly regulated. COCOBOD sets the domestic producer price in an annual review of the price at the beginning of each year prior to the actual harvest and export of cocoa. Among other factors such as the cost of production and price of inputs, 
this process of determining the appropriate price level includes projected exchange rates based partly on most recent exchange rates. This longstanding policy renders the actual exchange rate insignificant in the determination of domestic cocoa price as the price is fixed for the entire year and exchange rate transmission is prevented.

Both world cocoa price and its lag (two years) were not statistically significant in affecting the domestic price. With full market integration, there is complete spatial price transmission such that commodities are sold at equilibrium prices differing only by transfer costs when converted to a common currency across markets. However, this outcome follows from COCOBOD's aim to stabilize domestic prices through regulation in order to insulate rural cocoa farmers from price fluctuations in the world market.

This blunts the domestic cocoa price and market response to changes in the world price. There is therefore insignificant price transmission.

GDP was also not statistically significant in affecting the domestic cocoa price. As Ghana's main foreign exchange earner, cocoa is a traditional export crop with very little demand and thus supply on the domestic market. Local demand is not factored into the pricing of cocoa as production is mainly for export. Hence, GDP as an indicator of the level of purchasing power and demand on the domestic market fails to have any significant impact on the domestic producer price of cocoa.

The lag of domestic cocoa price (one year) did not have a statistically significant effect on the domestic price of cocoa. Again, the lack of a liberalized pricing system based solely on market forces in the Ghanaian cocoa subsector precludes the expected relationship between past and present prices.

The change measured by these estimates takes account of the short run effect of a change in the independent variables on the dependent variable. However in line with the objective of policymakers to be able to predict the eventual effects of policies, the ADL model estimates the long run effect (the long run multiplier) as;

$$
-\frac{\theta}{\rho}
$$

The long run multiplier is estimated using all the independent variables (excluding the lags). Therefore, the long run multiplier is;

$$
-\frac{(-0.177)+(0.111)+(0.293)}{0.114}
$$

Long run multiplier $=-1.992$.

This long run effect means if the exchange rate, world cocoa price and GDP together increase permanently by $1 \%$ in the long run, the equilibrium value of domestic cocoa price will correspondingly fall by $1.992 \%$. This negative relationship does not appear to be sensible as a positive relationship would rather be expected. However, the statistical information undermines this finding as the explanatory variables are not statistically significant in the estimation.

\subsection{Maize}

As shown in Table 2, the independent variables together accounted for $28 \%$ of the variation in the domestic price of maize in Ghana for the period under review. Both the exchange rate and its lag (one year) were not statistically significant in affecting the domestic price of maize. The degree of exchange rate transmission for a good is directly related to how intensively a country trades it such that the greater the share of exports in domestic production, the stronger the exchange rate pass-through tends to be. In Ghana, maize is produced mainly for domestic consumption, serving as the most important cereal crop. With an intermittent and often low export supply only in years of surplus production, the exchange rate has had little influence on the domestic price of maize.

Similarly, world maize price and its lag (two years) both did not have a statistically significant effect on the domestic price of maize. As non-traditional export crop, the maize market in Ghana is not well integrated with the world market such that there is little spatial price transmission and world maize price does not significantly account for the variability in domestic maize price.

GDP on the other hand had significant explanatory power for domestic maize price. Accordingly, a 1\% increase in GDP is associated with a $1.10 \%$ increase in domestic maize price. As maize is produced primarily for domestic consumption with the aim of food security in Ghana, the domestic producer price is responsive to the level of local demand. Hence, there is a direct relationship between GDP which reflects the level of purchasing power and demand in the country, and domestic maize price.

Table 1. ADL model for changes in domestic cocoa price

\begin{tabular}{lcccc}
\hline Variable & Coefficient & t-stat & P-value & [95\% Conf. Interval] \\
\hline Exchange Rate & -0.177 & -0.89 & 0.381 & -0.584 \\
Exchange Rate (1 year lag) & $0.356^{* * *}$ & $\mathbf{2 . 5 1}$ & 0.017 & 0.229 \\
World Price & 0.111 & 0.72 & 0.477 & 0.645 \\
World Price (2 year lag) & 0.054 & 0.43 & 0.673 & -0.203 \\
GDP & 0.293 & 1.08 & 0.289 & -0.202 \\
Domestic Price (1 year lag) & 0.114 & 0.57 & 0.569 & -0.261 \\
\hline
\end{tabular}

R-squared $=0.303$

Adj R-squared $=0.177$

Number of Obs $=40$

* Significant at the $10 \%$ level; ** Significant at the $5 \%$ level; *** Significant at the $1 \%$ level. 
Table 2. ADL model for changes in domestic maize price

\begin{tabular}{lccccc}
\hline Variable & Coefficient & t-stat & P-value & \multicolumn{2}{c}{ [95\% Conf. Interval] } \\
\hline Exchange Rate & 0.357 & 0.86 & 0.396 & -0.487 & 1.201 \\
Exchange Rate (1 year lag) & -0.347 & -1.27 & 0.215 & -0.905 & 0.211 \\
World Price & -0.288 & -0.76 & 0.455 & -1.064 & 0.488 \\
World Price (2 year lag) & 0.007 & 0.03 & 0.975 & -0.461 & 0.475 \\
GDP & $1.101^{* * *}$ & $\mathbf{2 . 1 2}$ & 0.042 & 0.424 & 2.159 \\
Domestic Price (1 year lag) & $-0.406^{* * *}$ & $\mathbf{- 2 . 4 5}$ & 0.020 & -0.743 & -0.069 \\
\hline
\end{tabular}

R-squared $=0.282$

Adj R-squared $=0.151$

Number of Obs $=40$

* Significant at the $10 \%$ level; ** Significant at the $5 \%$ level; *** Significant at the $1 \%$ level.

The lag of domestic maize price (one year) also had a significant effect on domestic maize price. Consequently, a $1 \%$ decrease in last year's annual average price will lead to a $0.406 \%$ increase in domestic maize price in Ghana. Given the free market system for maize in Ghana, higher producer prices stimulate higher production, and with increased supply, domestic prices in subsequent periods tend to fall.

The long run effect of the independent variables on domestic maize price is given by;

$$
-\frac{(0.357)+(-0.288)+(1.101)}{-0.406}
$$

Long run multiplier $=2.882$.

Therefore, in the long run if the exchange rate, world maize price and GDP together increase permanently by $1 \%$, the new equilibrium value of the domestic price of maize will increase by $2.882 \%$.

\section{Conclusions and Recommendations}

The findings of the study reveal that there is insignificant exchange rate transmission to the domestic producer prices of both cocoa and maize in Ghana. Therefore, nominal exchange rate changes do not significantly influence the domestic producer prices of cocoa and maize in Ghana. However, in the case of cocoa, it was found that past exchange rates have a quantitative effect on the domestic producer price. Last year's annual average exchange rate has a direct relationship with domestic producer price such that an increase in last year's exchange rate (depreciation of the Ghana cedi against the US Dollar) is associated with an increase in the domestic producer price of cocoa. Similarly, the results showed that world price transmission elasticities for both crops reflect insignificant effects on domestic producer price. Thus, domestic producer prices of cocoa and maize are not responsive to fluctuations in world cocoa and maize prices, respectively.

Market intervention and price fixing were identified as the main impediments to exchange rate and world price transmissions to the domestic producer price of cocoa in Ghana. COCOBOD's price setting and marketing policies aimed at price stability preclude exchange rate and world price pass-through to domestic producer prices. Conversely, the maize market in Ghana has effectively operated a liberalized market system since 1983. However, exchange rate and world price transmissions before and after the market reform remained insignificant, signaling other hindrances to exchange rate and world price pass-through.

It was found that GDP as a signal of the level of purchasing power and demand on the domestic market does not significantly impact on the domestic cocoa producer price as cocoa is mainly produced to meet export demand. The domestic producer price of maize on the other hand is responsive to demand on the domestic market as priority is placed on local supply over exportation. This accounts for the lack of exchange rate and world price transmissions to the producer price of maize in Ghana. Past studies have found comparable effects on domestic agricultural prices in other developing countries due to similar policy and institutional factors $[2,3,28]$

From a policy perspective, this study relates to trade liberalization in Ghana's agricultural sector. COCOBOD’s market intervention and price setting system in the cocoa sub-sector reveals the government's underlying objective to insulate Ghana's principal source of foreign exchange from instability in the world market. Consequently, in spite of reforms stemming from pressure from international donor organizations such as the World Bank and IMF to liberalize the sector, COCOBOD has retained control over the external marketing of cocoa and continues to set prices. It is expected that this policy of price stabilization will improve farmers' welfare and encourage production.

The government's agricultural policy for maize on the other hand has been more in line with the goal of food self-sufficiency rather than export promotion. Thus, even within a free market system this policy has inadvertently impeded exchange rate and world price transmissions to domestic price as farmers are encouraged to market their produce domestically.

In as much as market intervention has led to the stabilization of prices in Ghana's cocoa sub-sector, it has also kept domestic price, production and the exportation of cocoa from rising as much as possible as signaled by the very low exchange rate and world price transmissions. It may therefore be more beneficial for Ghana to further liberalize the cocoa sub-sector so as to be able to attain levels of production and trade that will lead to maximum economic benefit for farmers and the country. 


\section{Acknowledgements}

The author thanks Dr. Mike Reynolds for his useful comments during the research.

\section{Statement of Competing Interests}

The author has no competing interests.

\section{References}

[1] Abdulai, A. (2000). Spatial price transmission and asymmetry in the Ghanaian maize market, Journal of Development Economics, Vol. 63, pp. 327-349.

[2] Baffes, J. and Ajwad, M. (2001). Identifying price linkages: A review of the literature and an application to the world market of cotton, Applied Economics, Vol. 33, pp. 1927-1941.

[3] Baffes, J. and Gardner, B. (2003). The Transmission of World Commodity Prices to Domestic Markets under Policy Reforms in Developing Countries, The Journal of Policy Reform, Vol. 6, No. 3, pp. 159-180.

[4] Bhattarai, K. R. and Armah, M. K. (2005). The Effects of Exchange Rate on the Trade Balance in Ghana: Evidence from Cointegration Analysis. Hull, Centre for Economic Policy, University of Hull.

[5] Brinkman, H. (1999). Explaining prices in the global economy: A post-Keynesian model. Massachusetts, Edward Elgar Publishing.

[6] Brooks, J., Croppenstedt, A. and Aggrey-Fynn, E. (2009). Distortions to Agricultural Incentives in Ghana. In: Anderson, K. and Masters, W. A. (eds.), Distortions to Agricultural Incentives in Africa, Washington DC, World Bank, pp. 413-440.

[7] Damiani, O. (2003). Effects on Employment, Wages, and Labour Standards of Non-Traditional Export Crops in Northeast Brazil, Latin American Research Review, Vol. 38, No. 1, pp. 83-112.

[8] Dickey, D. A. and Fuller, W. A. (1979). Distribution of the Estimators for Autoregressive Time Series with a Unit Root, Journal of the American Statistical Association, Vol. 74, No. 336, pp. 427-431.

[9] Dordunoo, C. K. (1994). The Foreign Exchange Market and the Dutch Auction System in Ghana. Research Paper 24, Nairobi, African Economic Research Consortium.

[10] Enke, S. (1951). Equilibrium among spatially separated markets: Solution by electrical analogue, Econometrica, Vol. 19, pp. 40-47.

[11] Fold, N. (2002). Lead Firms and Competition in "Bi-polar" Commodity Chains: Grinders and Branders in the Global CocoaChocolate Industry, Journal of Agrarian Change, Vol. 2, No. 2, pp. 228-247.

[12] Gardner, B. L. (1975). The farm-retail price spread in a competitive food industry, American Journal of Agricultural Economics, Vol. 59, pp. 399-409.

[13] Institute of Statistical, Social and Economic Research (ISSER) (2010). The State of the Ghanaian Economy in 2009. Accra, Institute of Statistical, Social and Economic Research, University of Ghana.
[14] Jebuni, C. D., Sowa, N. K. and Tutu, K. A. (1991). Exchange Rate Policy and Macroeconomic Performance in Ghana. Research Paper 6, Nairobi, African Economic Research Consortium.

[15] Koop, G. (2009), Analysis of Economic Data, $3^{\text {rd }}$ Edition, Chichester, John Wiley.

[16] Leith, J. C. and Söderling, L. (2000). Ghana: Long Term Growth, Atrophy, and Recovery, Emerging Africa. Research Report 125, Paris, OECD.

[17] Liefert, W. and Persaud, S. (2009). The Transmission of Exchange Rate Changes to Agricultural Prices. Economic Research Report No. 76, Washington DC, U.S. Department of Agriculture, Economic Research Service.

[18] Liew, V. K. (2004). Which Lag Length Selection Criteria Should We Employ? Economics Bulletin, Vol. 3, No. 33, pp. 1-9.

[19] May, E. (1985). Exchange Controls and Parallel Market Economies in Sub-Saharan Africa: Focus on Ghana, World Bank Staff Working Paper No. 711, Washington DC, World Bank.

[20] Menon, J. (2006). Exchange Rate Pass-Through, Journal of Economic Surveys, Vol. 9, No. 2, pp. 197-231.

[21] Ministry of Food and Agriculture (MOFA) (2002). Food and Agriculture Sector Development Policy (FASDEP), Accra, Ministry of Food and Agriculture.

[22] Ministry of Food and Agriculture (MOFA) (2007). Food and Agriculture Sector Development Policy (FASDEP II), Accra, Ministry of Food and Agriculture.

[23] Ministry of Food and Agriculture (MOFA) (2010). Agriculture in Ghana, Facts and Figures (2009), Accra, Ministry of Food and Agriculture.

[24] Mumuni, Z. and Owusu-Afriyie, E. (2004). Determinants of the Cedi/Dollar Rate of Exchange in Ghana: A Monetary Approach, Bank of Ghana Working Paper WP/BoG-06, Accra, Bank of Ghana.

[25] Puplampu, K. P. (1999). The State, Agricultural Policies and Food Security in Ghana (1983-1994), Canadian Journal of Development Studies, Vol. 20, No. 2, pp. 337-359.

[26] Samuelson, P. A. (1952). Spatial price equilibrium and linear programming, American Economic Review, Vol. 42, pp. 560-580.

[27] Sanusi, A. R. (2010). Lessons from the Foreign Exchange Market Reforms in Ghana: 1983-2006, Journal of Economics and Allied Fields, Vol. 4, No. 2, pp. 1-19.

[28] Sharma, R. (2003). The Transmission of World Price Signals: Concepts, Issues, and Some Evidence from Asian Cereal Markets. In: Tangermann, S. and Burgeat, E. (eds.), Agricultural Trade and Poverty: Making Policy Analysis Count, Paris, Organisation for Economic Co-operation and Development, pp. 141-160.

[29] Sowa, N. K. (1994). Fiscal deficits, output growth and inflation targets in Ghana, World Development, Vol. 22, No. 8, pp. 11051117.

[30] Takayama, T. and Judge, G. G. (1971). Spatial and temporal price allocation models, Amsterdam, North-Holland.

[31] Ton, G., Hagelaar, G., Laven, A. and Vellema, S. (2008). Chain governance, sector policies and economic sustainability in cocoa: A comparative analysis of Ghana, Côte d'Ivoire, and Ecuador, Markets, Chains and Sustainable Development Strategy \& Policy paper No. 12, London, Stichting DLO: Wageningen.

[32] Werlin, H. (1994). Ghana and South Korea: Explaining Development Disparities, Journal of Asian and African Studies, Vol. 29, pp. 3-4.

Appendix 1: Lag Order Selection

\begin{tabular}{lcr}
\hline Variable & Number of Lags & AIC Criterion \\
\hline Domestic Cocoa Price & 1 & $-0.027544^{*}$ \\
World Cocoa Price & 2 & $0.749521^{*}$ \\
Domestic Maize Price & 1 & $1.131160^{*}$ \\
World Maize Price & 2 & $0.656014^{*}$ \\
Exchange Rate & 1 & $0.331277^{*}$ \\
GDP & 0 & $-0.926315^{*}$ \\
\hline
\end{tabular}

Number of Obs $=38$ 
Appendix 2: Durbin-Watson Test

a. Durbin-Watson Test for Cocoa data

\begin{tabular}{lcccc}
\hline Variable & Coefficient & t-stat & P-value & Lower 95\% \\
\hline lnExchange Rate & 0.1094018 & 1.27 & 0.212 & -0.0648849 \\
lnWorld Price & 0.2029271 & 1.63 & 0.111 & -0.0486704 \\
lnGDP & 0.6704225 & 7.93 & 0.000 & 0.2836886 \\
\hline
\end{tabular}

R-squared $=0.9958$

Adj R-squared= 0.9955

Durbin-Watson d-statistic( 4, 43) = 0.9942627

b. Durbin-Watson Test for Maize data

\begin{tabular}{lcccc}
\hline Variable & Coefficient & t-stat & P-value & Lower 95\% \\
\hline lnExchange Rate & -0.2791687 & -1.15 & 0.258 & -0.7713811 \\
lnWorld Price & -0.1075025 & -0.34 & 0.736 & -0.7476429 \\
lnGDP & 1.2609760 & 9.58 & 0.000 & 0.2130436 \\
\hline
\end{tabular}

R-squared $=0.9889$

Adj R-squared= 0.9881

Durbin-Watson d-statistic( 4, 43) = 1.093899

Appendix 3: Stationarity and Unit root test

a. Augmented Dickey-Fuller Critical Values

\begin{tabular}{|l|c|c|c|}
\hline$\Delta y_{t}=\alpha_{0}+\gamma y_{t-1}+v_{t}$ & $\mathbf{1 \%}$ & $\mathbf{5 \%}$ & $\mathbf{1 0 \%}$ \\
\hline At Level & -3.634 & -2.952 & -2.610 \\
\hline $\mathbf{1}^{\text {st }}$ Difference & -3.641 & -2.955 & -2.611 \\
\hline
\end{tabular}

b. Augmented Dickey-Fuller test results for all the variables (logged)

\begin{tabular}{|c|c|c|}
\hline Variable & At level & $1^{\text {st }}$ Difference \\
\hline Domestic Cocoa Price & -0.382 & -4.722 \\
\hline World Cocoa Price & -0.417 & -4.369 \\
\hline Domestic Maize Price & -0.336 & -8.294 \\
\hline World Maize Price & 0.095 & -4.572 \\
\hline Exchange Rate & -0.058 & -3.617 \\
\hline GDP & 0.896 & -5.277 \\
\hline
\end{tabular}

